NBER WORKING PAPER SERIES

\title{
IMPROVING COLLEGE PERFORMANCE AND RETENTION THE EASY WAY: UNPACKING THE ACT EXAM
}

\author{
Eric P. Bettinger \\ Brent J. Evans \\ Devin G. Pope \\ Working Paper 17119 \\ http://www.nber.org/papers/w17119 \\ NATIONAL BUREAU OF ECONOMIC RESEARCH \\ 1050 Massachusetts Avenue \\ Cambridge, MA 02138 \\ June 2011
}

We are grateful to seminar participants at Notre Dame and Stanford University and to Brent Hickman and Emily Oster for helpful comments and suggestions. We also thank Darrell Glenn and Andy Lechler from the Ohio Board of Regents for providing the data. The views expressed herein are those of the authors and do not necessarily reflect the views of the National Bureau of Economic Research.

NBER working papers are circulated for discussion and comment purposes. They have not been peerreviewed or been subject to the review by the NBER Board of Directors that accompanies official NBER publications.

(C) 2011 by Eric P. Bettinger, Brent J. Evans, and Devin G. Pope. All rights reserved. Short sections of text, not to exceed two paragraphs, may be quoted without explicit permission provided that full credit, including $\odot$ notice, is given to the source. 
Improving College Performance and Retention the Easy Way: Unpacking the ACT Exam Eric P. Bettinger, Brent J. Evans, and Devin G. Pope

NBER Working Paper No. 17119

June 2011

JEL No. I23

\section{ABSTRACT}

Colleges rely on the ACT exam in their admission decisions to increase their ability to differentiate between students likely to succeed and those that have a high risk of under-performing and dropping out. We show that two of the four sub tests of the ACT, English and Mathematics, are highly predictive of positive college outcomes while the other two subtests, Science and Reading, provide little or no additional predictive power. This result is robust across various samples, specifications, and outcome measures. We demonstrate that focusing solely on the English and Mathematics test scores greatly enhances the predictive validity of the ACT exam.

Eric P. Bettinger

Stanford School of Education

CERAS 522, 520 Galvez Mall

Stanford, CA 94305

and NBER

ebettinger@stanford.edu

Brent J. Evans

School of Education

Stanford University

bjevans@stanford.edu
Devin G. Pope

Booth School of Business

University of Chicago

5807 South Woodlawn Avenue

Chicago, IL 60637

and NBER

devin.pope@chicagobooth.edu 


\section{Introduction}

College performance and timely graduation are increasingly important policy issues. After six years, 35 percent of students who started a post-secondary program in Fall 2003 had not received a degree and were no longer enrolled in any institution of higher education (Radford et al., 2010). Additionally, many students who are capable and qualified to attend selective colleges "undermatch" and attend less-selective institutions where they are less likely to graduate (Bowen, Chingos, and McPherson 2009). This high dropout rate can be costly for the students who drop out, the students who could have been admitted in their stead, the colleges, which must devote significant resources to recruiting and orienting new students, and society which relies on college graduates to promote economic growth in an increasingly skill-based economy.

The education literature has discussed many possibilities for boosting college retention rates, such as removing financial obstacles (Dynarski, 2003, Singell, 2004), preparing high-school students better (DeBrock et al., 1996; DesJardins, Ahlburg, and McCall, 2002), improving the quality of the match between universities and students (Bowen, Chinos, and McPherson 2009), and improving the social and academic integration of students (Spady, 1970; Tinto, 1975; Bettinger and Baker, 2011). All of these likely reflect important factors in retention and performance. However, these solutions can also be costly and hard to implement.

In this paper, we focus on one important element of the admission decision, standardized test scores, in an effort to understand the predictive validity of these scores on college performance and retention. Specifically, we examine the difference in predictive validity of each individual subject sub score on students' likelihood of persisting in college. Improvements in admission offices' understanding of the value of each subject test may lead to improved selection of students and reduced dropout rates.

The ACT, a term that originally stood for American College Testing, is a standardized U.S. college admissions exam. It has been growing in popularity, pulling even with its main competitor, the SAT (formerly, Scholastic Aptitude Test), in the total number of student test takers (Kaplan, 
2009). The ACT covers four subjects: Mathematics, English, Reading and Science. ${ }^{2}$ Scores from 1-36 on each of these components and an all-important composite score are provided to colleges for their use in admission decisions. The composite, a score from 1-36, is the rounded average of the scores on the four individual sections. Nearly all colleges indicate that they use solely the ACT composite score in their admissions process. ${ }^{3}$ A common conversion chart developed by ACT Inc. and the College Board (publisher of the SAT) maps ACT composite scores against SAT scores for colleges that accept both ACT and SAT exams, as almost all four-year colleges do.

By using the ACT composite score, college admissions offices implicitly give equal weight to each of its four individual sub tests; however, this practice is not required. It is possible to weight the four ACT sub scores based on their individual predictive power. In this paper, we explore the possibility that the individual sub scores differ in their ability to predict college outcomes.

We test for differences in predictive power among the four sub scores using Ohio Board of Regents data on all students that matriculated in 1999 to a four-year public college in Ohio. Along with demographic information about each student, the data contain important college performance measures such as Grade Point Average (GPA) and indicators for dropping out.

Not surprisingly and confirming a long line of literature, we find a strong correlation between higher ACT composite scores and positive college outcomes. However, this overall correlation masks an important pattern: Mathematics and English scores are much more tightly correlated with college success than are Reading and Science scores. In fact, after controlling for Mathematics and English scores, Reading and Science provide essentially no predictive power regarding college outcomes.

The difference in the predictive ability for Mathematics and English versus Reading and Science scores is consistent across different specifications and data sub samples. The finding is robust when controlling for indicators of the college that students attend, high school performance, student demographics, and college major. The results are also consistent across a wide variety of

\footnotetext{
2 Post-dating our data sample, an optional writing test was introduced in February 2005, mirroring changes to the SAT that took place in the same year.

${ }^{3}$ We provide survey evidence from admissions offices to substantiate this claim.
} 
college outcomes including GPA for the first and second years and dropout rates for the first and third years. The results are very similar across different universities of varied quality. We also find that Mathematics and English scores are far better predictors than Reading and Science scores of high school GPA. This provides further evidence that the Reading and Science tests have very little predictive merit. Finally, we replicate our results using a smaller independent data source from a private university in the Western United States.

The effects that we find are large enough to cause an economically important difference in predictive ability. For example, our model predicts that a student who gets an ACT composite score of 24 by getting a 26 each on the Reading and Science tests and a 22 each on the Mathematics and English tests is 59 percent more likely to be a first-year dropout and 43 percent more likely to drop out by the third year of college, relative to a student who gets the same ACT composite score of 24, but with a 26 each on the Mathematics and English tests and a 22 each on the Reading and Science tests. $^{4}$

By introducing noise that obscures the predictive validity of the ACT exam, the Reading and Science tests cause students to be inefficiently matched to schools - admitted to schools that may be too demanding - or too easy - for their levels of ability. To explore a potential increase in predictive validity of the exam, we generate a Math-English composite measure that gives equal weight to the Mathematics and English test scores and zero weight to the Reading and Science scores. Clearly a composite score that is based on the Mathematics and English sub tests will be highly correlated with the current ACT composite score. However, we show that these two measures of performance (ACT composite vs. Math-English composite) are different enough to cause large changes in admission outcomes.

For example, we conduct a simple calibration test that estimates the number of students that would be matched to a different Ohio college were the Math-English composite measure to be used. Under strong assumptions, we estimate that as many as 55 percent of the students in Ohio would

\footnotetext{
${ }^{4}$ The $59 \%$ and $43 \%$ increase in the probability of dropping out comes from a 5.2 and 10.4 percentage point increase with a base dropout rate of $8.8 \%$ and $23.9 \%$ in the first and third year, respectively. It is also important to note that this example does not represent an out-of-sample result. More than $20 \%$ of the students in our data have an average Mathematics and English score that is either 2 points higher or 2 points lower than their overall ACT composite score.
} 
either move to a more or less selective school due to this more accurately predictive measure. We further calibrate how using an ACT measure based solely on the English and Mathematics subtests would impact the various colleges in our sample. We find that the top schools - who we assume get first choice when selecting students - would experience dropout rate reductions as large as 5-7\%.

We also consider the likelihood that a college's selection goals extend beyond building a student body that gets good grades and graduates. For example, diversity of race, gender and major may all be important factors for universities to consider when admitting students. We find no evidence that using just the Mathematics and English sub scores would have an adverse impact on minority admission rates and or admission rates by gender. We do, however, find evidence that students that are more likely to major in the sciences would slightly benefit from switching toward an admission score which only relies on the Mathematics and English sub scores. We conclude with a puzzle of why college admissions offices use all four sub scores in their admission processes. We suggest several possibilities, including the worry that it could hurt their standing in external rankings.

This paper contributes to the literature on the relationship between standardized test scores and college outcomes (Munday, 1967; Bowen and Bok, 1998; Burton and Ramist, 2001; Rothstein, 2004). Most recently, some have argued for eliminating the use of standardized tests in college admissions due to concerns that scores serve as proxies for other measures such as socioeconomic and minority status (e.g. Rothstein, forthcoming). Our paper does not take a side in this debate, as we are chiefly concerned with identifying differences in the predictive validity of the individual subject tests as a way to use standardized test scores in the admission process efficiently.

The remainder of the paper proceeds as follows. Section 2 provides a more detailed description of the ACT test along with survey evidence of how the test is used by colleges in admissions. Section 3 describes the data used in our analyses and outlines the basic empirical framework. Section 4 presents our results, including a variety of robustness checks and additional analyses. Section 5 concludes with a brief discussion of ways to improve the use of standardized test scores and the broader implications of this research. 


\section{The ACT Exam}

The ACT is a national college admission examination, first administered in 1959 as a competitor to the College Board's SAT. Based in Iowa City, Iowa, the ACT has grown in popularity substantially since 1959. A recent article in Fortune magazine suggested that the SAT and ACT had equal market shares in recent years (Kaplan, 2009). Although the test is most popular in the South and Midwest, ACT results are accepted by all four-year colleges and universities in the United States.

The ACT consists of four multiple-choice sub-tests: Mathematics, English, Reading and Science. The Mathematics component is a 60-question, 60-minute test that covers basic math concepts that students typically learn by 11 th grade. The English component is a 75 -question, 45minute test covering basic usage and mechanics of the English language, as well as rhetorical skills. The Reading component is a 40-question, 35-minute test that measures reading comprehension. The Science component is a 40-question, 35-minute test that measures a variety of science-related skills including data interpretation, analysis, evaluation and basic problem solving. A student receives a whole-number score from 1-36 on each of these tests. ACT Inc. markets the four-subject design as a superior test vehicle and promotes ACT as testing the actual high school curriculum, not serving as an aptitude or IQ test, ${ }^{5}$ and at least five states (Illinois, Michigan, Kentucky, Colorado, and Wyoming) require high school graduates to take the ACT exam.

When students tell ACT Inc. where to send their test scores, the company provides each of the four sub test scores along with a composite score, the average of the four rounded to the nearest whole number. This composite is central to admissions. First, many schools (especially state schools) use an ACT composite score cutoff for guaranteed admission. For example, in California, applicants are guaranteed admission to the UC system if they reach certain SAT and high school GPA thresholds (see Rothstein (2004) for a more detailed discussion). In this automatic admission process, ACT composite (not the individual sub) scores are used to map ACT scores against SAT scores, which then are used as the cutoff. Even when schools do not set a specific ACT composite cutoff for admission, the score is generally described as the standardized test statistic used

\footnotetext{
${ }^{5}$ Information for this paragraph was obtained from ACT Inc.'s website: http://www.act.org/.
} 
in the admission process. A review of college admissions office websites makes this clear. However, we also conducted a detailed survey of college admissions offices for the purposes of this study. Specifically, in October 2009, we interviewed admissions officers by phone, at all 13 of Ohio's fouryear public colleges (the colleges in our data). Although respondents ranged from the dean of admissions to lower-ranked admissions officers, all respondents reported that they read applications and make admission decisions for their institutions. The interviews' primary purpose was to determine how each admissions office has used the ACT composite and individual test scores. The full interview protocol is provided as Appendix 1.

On the critical point of whether the composite or component scores are more often used, the result is clear: despite the availability of the subject-specific component scores, all of the institutions rely on the composite ACT score to make their admission decisions. Although the composite score is clearly the primary statistic used, a few nuances are worth mentioning. For example, one of the colleges interviewed indicated that it considers individual subject scores in rare situations. Specifically, for "strivers," students who perform better than expected given their poorperforming high school, the university at times considers individual sub scores as a way of understanding what makes the student special. Another institution noted that they might look at an individual sub score if a student's grades in a particular subject are very weak. For example, if a student is consistently getting D's in the sciences but is otherwise a B student, the Science score may be used to provide further information. Finally, although admission decisions are made using the composite score, some colleges use individual test scores as a requirement to get into certain majors after the student enrolls. Despite these complicating factors, the fact remains that these schools by and large simply use the composite score in their admission decisions. No school indicated that they use only a subset of the test scores or that they re-weight individual test scores to create a new composite measure.

\section{Data and Empirical Framework}


We obtained our primary dataset from the Ohio Board of Regents. The data contain information on all students who matriculated to a public four-year public university in Ohio in 1999. Thirteen schools fit this description: The University of Akron, Bowling Green State University, Central State University, University of Cincinnati, Cleveland State University, Kent State University, Miami University, The Ohio State University, Ohio University, Shawnee State University, The University of Toledo, Wright State University and Youngstown State University.

The data provide information about the demographic characteristics of students (race, age and gender), their high school academic performance (ACT scores and student-reported high school GPA), and college information (campus attended, major chosen, first and second year GPA, and indicators for dropping out in the first, second and third years).

For several reasons, these data are ideal for studying the differential predictive power of individual ACT tests. First, the Ohio college system has more ACT than SAT students. According to McDaniel (2006), 66 percent of Ohio's 2005 high school graduates took the ACT whereas only 29 percent took the SAT. Second, the Ohio public-university system offers campuses that vary in student ability and academic standards. For example, the major universities are distinguished by their academic rigor (e.g. Ohio State University, Ohio University and Miami University) ${ }^{6}$, while other, smaller campuses generally admit students with lower test scores (e.g. Cleveland State, Central State and Shawnee State). This diversity allows us to address the predictive power of the ACT more broadly than if our data were limited to just one or two institutions. Third, and finally, the data include very important college outcome variables (GPA and dropout rates) at an individual level linked to ACT scores.

Table 1 provides summary statistics for the 25,645 ACT-taking students in our sample. Of particular interest, our sample has a dropout rate of nine percent in the first year and 24 percent by the third year. The sample is slightly more female like most of higher education (54\% female) and is predominantly white (85\%). The average ACT composite score in our sample is approximately 22 ,

\footnotetext{
${ }^{6}$ These schools are ranked 56th, 124th and 79th respectively in the 2011 U.S. News \& World Report college ranking (U.S. News \& World Report, 2011).
} 
which is at the 62 nd percentile nationally. Table 1 also provides means and standard deviations for each individual ACT test.

Our empirical strategy is simple. We are interested in understanding the additional predictive power that each of the test scores provides conditional on the other scores. Our most basic empirical specification is:

$$
\text { Outcome }_{i}=\alpha+\beta_{1} \text { Mathematics }+\beta_{2} \text { English }+\beta_{3} \text { Reading }+\beta_{4} \text { Science }+\varepsilon_{i} .
$$

wherein the outcome for each individual $i$ will be either GPA or an indicator for dropping out, and the four main independent variables represent the test score (from 1-36) on the Mathematics, English, Reading, and Science ACT tests. For robustness, we will also present results from specifications that include controls such as demographic variables, high school GPA, major fixed effects, and campus fixed effects.

Assuming that the objective function of the university is the outcome variable of the regression, then college admissions offices ideally should use the weights associated with each test score $\left(\beta_{1}, \beta_{2}, \beta_{3}, \beta_{4}\right)$ in the admission process. We are interested in testing the null hypothesis that $\beta_{1}=\beta_{2}=\beta_{3}=\beta_{4}$, which we argued in the previous section is the manner in which these scores are currently being used in the admission process.

\section{Results}

\subsection{Main results}

Using our basic specification in Equation (1), Table 2 estimates the ability of the ACT to predict first-year college GPA. Column (1) provides the simple correlation between first-year GPA and the ACT composite score. Not surprisingly, the ACT composite score has a large and significant impact on first-year GPA: A one point increase in the ACT composite score is associated with a .072 increase in GPA.

Column (2) of Table 2 breaks down the ACT score into its four components. The results show a large and significant impact of both the Mathematics and English score on GPA. A one point increase in either of these test scores is associated with an approximately .035 increase in GPA. 
The ACT Reading test, on the other hand, shows a significant, but much smaller association with GPA (.005 increase in GPA per ACT test point). Finally, the point estimate on the ACT Science test score is small and actually negative. ${ }^{7}$ The results from this specification indicate a clear difference in the predictive validity of the four sub scores for freshman GPA. After controlling for the other test scores, Mathematics and English scores have large effect sizes that are seven to nine times as large as the Reading and Science scores, which have small or even slightly negative effect sizes. The formal test of the hypothesis that all of the coefficients are equal is roundly rejected (F-statistic of 115 and p-value less than 0.000).

The effects observed in Column (2) raise a concern that students with different sub scores may differ on other, unrelated factors that could be linked spuriously with lower or higher GPAs. For example, it is possible that students with high Reading scores purposely choose colleges that grade more strictly. Concerns of this type can be addressed by controlling for some basic student and school characteristics. In Columns (3)-(6) of Table 2, we once again regress first-year GPA on the four ACT sub scores, this time including increasingly detailed controls: campus, high school GPA, race and gender, and college major fixed effects. As expected, the effect size for the ACT scores shrink as other controls (e.g. high school GPA) are included due to ACT scores' high correlation with controls. However, the relative predictive power of the Mathematics and English scores compared with the Reading and Science scores remains. Mathematics and English continue to be strong predictors of first-year GPA (in some specifications, Mathematics a bit more than English) whereas Reading and Science have very limited predictive validity.

Table 3 presents an analysis like that in Table 2, using second-year GPA as the dependent measure. The effects are nearly identical to those of Table 2. Mathematics and English tests are highly predictive of second-year GPA, while Reading shows a small positive effect and Science shows a small negative effect. Once again, a formal test of the hypothesis that all of the coefficients are equal is rejected (F-statistic of 152 and p-value less than 0.000).

\footnotetext{
${ }^{7}$ The consistently negative effects that we find on the Science test score (and Reading test score in the dropout regressions) may be driven, in part, by school mismatch. A high Science or Reading score may not be indicative of academic ability, but may cause a student to get into a school for which they are not a good fit. This mismatch may help explain the small but negative estimates that we find.
} 
Table 4 uses first-year dropout rates as the dependent variable. For this analysis, we utilize logit regressions and present marginal effects. Once again, Column (1) shows a large association between the ACT composite score and dropout rates. Column (2) breaks down the results by individual test score. Mirroring the GPA tables, the estimates suggest that a student with a one point higher Mathematics or English score is .65 or .46 percentage points less likely to drop out, respectively. Conversely, the Reading and Science test scores both have insignificant coefficients with the opposite sign.

Columns (3)-(6) of Table 4 test the relationship between ACT sub scores and first-year dropout rates while including additional controls. The Mathematics and English test scores continue to have a strong and significant association with lower dropout rates, yet higher Reading and Science scores are actually associated with higher dropout rates (with the Reading coefficient being statistically significant).

Table 5 shows what happens when the dependent variable indicates whether students dropped out by their third year of college. Once again, higher Mathematics and English scores predict lower dropout rates while Reading and Science scores predict small but higher dropout rates. We are able to strongly reject the hypothesis that all of the coefficients are equal (Chi-squared test statistic of 190 and p-value less than 0.000).

\subsection{Heterogeneity analysis}

For our results to be useful, it is important to know if the difference in predictive power across ACT sub tests is driven by school type; in other words, if the effect is consistent across the range of schools. By looking at data from the different schools in our sample, we can consider the consistency of the effects that we find.

Table 6 estimates the impact of ACT test scores on first-year college GPA by university. ${ }^{8}$ Our basic empirical finding is extremely robust across schools. For all schools in the sample, both the Mathematics and English scores strongly and significantly predict higher first-year GPAs. This

\footnotetext{
${ }^{8}$ The last column groups the 5 schools in the sample with the smallest number of observations (Youngstown State, Wright State, Shawnee State, Cleveland State and Central State).
} 
correlation is not notably different for the more or less competitive schools. We also find an insignificant impact of Science and Reading scores on academic success for nearly all of the schools in the sample (the Reading test has a small but significant effect in two schools).

Table 7 shows a similar picture for third-year dropout rates. Although statistical power is limited when looking at dropout rates by university, we once again find that higher Mathematics and English scores are negatively correlated with dropping out (i.e., the higher the scores, the less dropping out). The effects are larger for Mathematics than English, but both are frequently statistically significant. Higher Reading and Science scores, on the other hand, are typically positively correlated with dropping out although rarely at a level of significance.

Overall, these results suggest that our basic finding holds across schools of varying academic standards.

\subsection{Correlation between ACT test scores and high school GPA}

Our main results suggest that after controlling for the Mathematics and English tests, the ACT Reading and Science tests do not predict college success. Given ACT Inc.'s assertion that its test follows the high school curriculum, it is possible that the Reading and Science tests are good at measuring skills that were useful in high school, but that are not useful for college performance. To test this possibility, we simply use high school GPA as our dependent variable.

Table 8 provides the results from this regression. The first column shows that higher ACT composite scores are indeed positively correlated with higher high school GPAs. ${ }^{10}$ However, Columns (2) and (3) show very clearly that Mathematics and English scores are much more correlated with high school GPA than Reading and Science scores. Whereas Reading and Science scores in this regression are positively correlated with high school GPA, the effect sizes are an order of magnitude smaller than the effect sizes for the Mathematics and English tests. These results

\footnotetext{
${ }^{9}$ Our data do not contain exact high school GPA scores, but a standardized scale from 1-7 for the high school GPA of each student recorded at the time they took the ACT.

${ }^{10}$ We report OLS coefficients in Table 8. Ordered Probit coefficients (unreported) provide qualitatively similar results.
} 
suggest that the Reading and Science tests are not as good as the Mathematics and English tests at predicting success in either high school or college.

\subsection{ACT scores and college performance in an independent sample}

In addition to Ohio public school data, we also have a small dataset from Brigham Young University - a private university in the Western United States - that was obtained for a different research project. This dataset is limited in many ways: It is a small sample (1,712 students who were first-time freshmen in 1997 or 1998 and graduated by the summer of 2005), and the only available outcome variables are high school and college GPA. However, these data provide one more check of robustness to see if our basic results hold in a completely different part of the country and with a private institution.

Table 9 provides the estimates when college GPA and exact high school GPA are included as dependent variables. Once again, we find that the Mathematics and English ACT scores are significantly correlated with both high school and college GPA. Reading scores have a smaller but still significant correlation with college GPA and no correlation with high school GPA, once we control for the other test scores. The Science test score is not significantly correlated with either college or high school GPA.

\subsection{Using a reweighted ACT composite measure}

The results that we have presented thus far suggest that the individual ACT sub scores have different levels of power to predict college performance and retention. Specifically, students with the same composite score are more likely to have positive outcomes when they achieved that score by doing well on the Mathematics and English tests than on the Reading and Science tests.

To illustrate this, we have created a simple ACT statistic as a potential alternative to the ACT composite score. The alternative measure that we use is the average of the Mathematics and English test scores (as opposed to the average of all four test scores). This new Mathematics-English 
composite score is clearly motivated by our finding that these two tests scores have unique predictive power whereas Reading and Science scores do not.

In Table 10, we illustrate the predictive power of the Mathematics-English composite score, while controlling for the traditional ACT composite score. ${ }^{11}$ In this table, we provide results for all four of our college outcome variables. The first column for each outcome variable provides results with no controls other than the ACT composite score, while the second column for each outcome variable includes the full set of control variables. We find that the Mathematics-English composite score provides significant predictive power even after controlling for the ACT composite score. For example, while controlling for the ACT composite score, we find that a 1 point increase in the Mathematics-English composite score is associated with a .066 increase in first-year GPA and a .060 increase in second-year GPA (.040 and .036, respectively, with controls). This means that a student who obtained an ACT composite score of 24 by getting a 26 on both the Reading and Science tests and a 22 on both the Mathematics and English tests is predicted to have an approximately .24 lower GPA after the second year of college than a student who got the same ACT composite score of 24 by getting a 26 on both the Mathematics and English tests and a 22 on both the Reading and Science tests.

We find similarly large effects for dropout rates. While controlling for the ACT composite score, we find that a 1 point increase in the Mathematics-English composite score results in a 1.3 percentage point reduction in the probability of dropping out in the first year and a 2.6 percentage point reduction in the probability of dropping out by the third year (.8 and 1.3 percentage points, respectively with controls). Given the base first and third-year dropout rates in our sample $(8.8 \%$ and $23.9 \%$ ), these represent large percentage changes.

For example, a student that obtained an ACT composite score of 24 by getting a 26 on both the Reading and Science sections and a 22 on both the Mathematics and English sections is predicted to be 59 percent more likely to drop out in the first year and 43 percent more likely to

\footnotetext{
${ }^{11}$ In this regression, we actually control for the unrounded ACT composite score produced by the ACT company. We do this so that our results are solely driven by the differences in predictive power across the individual tests and not by the fact that the composite score that the ACT company provides is rounded. Our results are slightly larger if we control only for the rounded ACT composite.
} 
drop out by the third year (5.2 and 10.4 percentage points) than a student that obtained the same composite score of 24 by getting a 26 on both the Mathematics and English sections and a 22 on both the Reading and Science sections.

These effects can also be seen graphically. In Figure 1, we plot the first and second year college GPA against the difference between our Mathematics-English composite score and the ACT composite score. There is a clear upward-sloping pattern in which doing better on the MathematicsEnglish composite relative to the overall ACT composite score is associated with higher GPAs. Similarly, in Figure 2, we see a strong negative relationship between scoring well in Mathematics and English (relative to the ACT composite) and dropping out. This figure once again shows that the Mathematics-English composite score can predict large differences in academic success even when controlling for the ACT composite score.

\subsection{The impact of using the reweighted composite measure on other outcomes}

Academic performance (GPA) and retention are surely two of the most important aspects of a university's mission, but colleges are still likely to care about many other things related to students and their performance. For example, even if Reading and Science scores have little power to predict college GPA and persistence, perhaps they predict other metrics valued by institutions of higher education such as diversity in demographics and interests. We are not able to test all possible issues that may concern admissions offices (e.g. we cannot test, for example, whether higher Reading and Science scores are associated with a student being more likely to join a club - which a university may value), however, we can look at three important issues: race, gender and choice of major.

One could try to understand the predictive validity of Science and Reading tests in many ways. For example, we have regressed indicators for minority, gender and major on the ACT and Mathematics-English composite scores separately, comparing the coefficients to see if one is more highly correlated with these demographics than the other. When we do this, we find that the Mathematics-English composite score is less associated with minority status and gender than the 
ACT composite score and more strongly associated with Science major than the ACT composite score. However, none of these coefficients are significantly different.

Perhaps a more intuitive way of answering this question, however, is to do a simple calibration. We begin by ranking all students in our sample from 1 to 25,645 based on the ACT composite score wherein 1 represents the highest (best) ACT composite score and 25,645 represents the lowest (worst). ${ }^{12}$ We then rank the students again from 1 to 25,645, this time using the Mathematics-English composite score. Once we have these two different rankings for each student, we can easily see the impact of the Mathematics-English composite ranking on the different subgroups relative to the ranking that uses the ACT composite only. In comparing the two rankings, we observe that the Mathematics-English composite ranking results in 1,654 minority students rising in rank and 1,498 dropping in rank (the average minority student rank improves from 17,378 to 17,260) relative to the ACT composite. The Mathematics-English composite ranking, therefore, has a positive effect on minority rank. Conversely, males are slightly hurt by the Mathematics-English composite ranking; 5,781 rise in rank and 5,880 move down. Overall, the average male rank decreases from 12,145 to 12,186. Lastly, students who choose science majors are helped by the Mathematics-English only system; 2,579 increase in rank compared to 2,228 that decrease. Overall, the average rank of a student majoring in science rises from 9,366 to 9,149.

These results suggest that the greater predictive validity of the English and Math subject tests in GPA and retention are not offset by adverse effects on minority students and that the two subject composite score has small positive effects for women and science oriented students relative to the full four subject composite score. ${ }^{13}$

\subsection{Calibrating the overall impact of using a Mathematics-English composite score}

\footnotetext{
${ }^{12}$ Once again, we use the unrounded ACT composite score for this exercise. To break ties, we create a random number that is used across all calibration so that score ties are broken in the same way.

13 These effects are, of course, partial equilibrium effects. If a university admits more science-oriented students, some students that otherwise would have taken science courses may sort into a non-science major.
} 
We have shown large differences in college outcomes among students who achieved the same ACT composite score with different combinations of sub scores. We now assess how accounting for the differential predictive validity of subject scores might affect the allocation of students to colleges.

Mathematics-English composite scores vary substantially, even within a given ACT composite score. For instance, the example that we used earlier, comparing students who had a Mathematics-English composite score either 2 points higher or lower than the ACT composite score, is not unrealistic. Twenty-two percent of the students in the sample have MathematicsEnglish composite scores 2 or more points different from their ACT composite score. This suggests that if students were judged exclusively on their two exam scores containing all of the predictive validity, many would be matched to different colleges than those in which they actually enrolled. To explore this further, we conduct a simple calibration.

We begin by assuming that Ohio is a closed college system and that students who matriculated to one of the Ohio schools in our sample would still do so even if all schools began to use the Mathematics-English composite score for admissions. We also assume that schools do not use any information other than ACT scores during the admissions process. ${ }^{14}$ Finally, we will assume that the highest-ranked school in Ohio (based on U.S. News \& World Report rankings) is allowed to fill its entering undergraduate cohort with its choice of all students in the sample, followed by the secondhighest ranked school, etc. Under these assumptions, we can explore the impact of relying solely on the Mathematics-English composite score. Under the first admissions rule, the top-ranked school in our sample would fill its freshman class with students starting with those who received an ACT composite score of 36 and then move progressively down to lower scores. ${ }^{15}$ Under the second rule, the top-ranked school in our sample would fill its freshman class with students starting with those that received a 36 on the ACT Mathematics and English tests and then move progressively down to lower Mathematics-English scores.

\footnotetext{
${ }^{14}$ We recognize that this is clearly an oversimplification. Our interview results suggest that admission offices place between 30 to 50 percent of their weight on ACT scores in the admission decision.

15 Ties are broken using a random number that is generated for each student. This random number is chosen to be the same across both admission rules so that changes in student placement are not being affected by differences in tie breaks.
} 
The results of this simple calibration indicate that the schools to which students are admitted vary greatly with the admission criteria used. Specifically, we find that 55 percent of students would be in a different school if the Mathematics-English composite score were used as the admission criterion instead of the ACT composite score. This scenario rests on some strong assumptions, such as colleges basing admissions decisions solely on ACT scores and students always choosing to enroll in the best ranked school. To the extent that colleges use other criteria in the admission process (e.g. high school GPA), the ACT score will have a smaller impact. It is possible, however, that even under these strong assumptions we could have found that very few students would be admitted to different schools. That would be the case were there not a lot of variation in the MathematicsEnglish composite score within a given ACT composite score. However, the calibration finding that up to 55 percent of students may be mismatched (under or over placed in the admission process) implies a great deal of variation, and that the ACT and Mathematics-English composite scores, although correlated, make many unique and independent predictions about which students will excel.

One further question that our calibration exercise can answer is the impact of moving from using the current ACT composite score to our proposed Mathematics-English composite score on individual universities in our dataset. We analyze this by simply comparing the 3rd-year dropout rate for the students that in our calibration are assigned to each school using the ACT composite measure and for the students assigned to each school using our proposed composite measure.

Table 11 provides the calibration results. The table lists the universities in our sample in order of their academic rating (Miami University being the highest rated and Central State University being the lowest rated). The first column provides the realized 3rd-year dropout rates for the students that would be assigned to each of these universities if students are admitted based on their ACT composite score while the second column provides the results if students are admitted based on their Mathematics-English composite score.

The results show that if admission decisions were based on the Mathematics-English composite score as opposed to the ACT composite score, the highest-rated universities in our 
sample would experience a 5-7\% decrease in their dropout rate while the lowest-rated universities would experience a 5-7\% increase in their dropout rate. The intuition for this result is that the top schools would pass on students that had a high ACT composite score that was largely achieved by doing well on the non-predictive Reading and Science tests. Their new set of students would be of higher quality, thus reducing their dropout rate. The lowest-rated schools in our sample end up with students not selected by the higher-rated universities. These students scored poorly overall on the ACT, but especially scored poorly on the Reading and Science exams. This results in a lower-quality student population and, therefore, a higher dropout rate.

\section{Discussion and Conclusions}

We have explored the predictive power that each of the four individual ACT tests have on college success. Despite the fact that colleges treat these test scores as if they have equal predictive value, we find that the Mathematics and English tests have significantly more predictive power than the Reading and Science tests. We consider whether reliance on the Reading and Science tests provides benefits beyond predicting college GPA and retention and conclude the scores have little power to assist colleges with any diversity goals related to minority status, gender, or major.

The predictive validity of standardized tests is relevant to policy and social welfare. If undermatching (Bowen, Chingos, and McPherson 2009) places good students in support systems which will not help them continue in college, then the graduation rates for these students may decrease. Reducing undermatching could end up increasing graduation rates if it improves access to the support systems that students may not otherwise have access to. Moreover, to the extent that a degree from a more selective college is more valuable than a degree from a less selective college (Brewer, Eide, and Ehrenberg, 1996), placing students who are less likely to drop out at the more selective schools can be welfare enhancing.

An obvious question is why, in the competitive college admissions market, is there so little variability in how ACT scores are used to make admission decisions. One could easily imagine colleges deciding to weight subject scores differently based on their own goals and student 
population. The answer is not clear. Personal conversations suggest that most admission officers are simply unaware of the difference in predictive validity across the tests and have limited time and resources to analyze the predictive power of its various components at their institution. An alternative explanation is that schools have a strong incentive - perhaps due to highly publicized external rankings such as those compiled by U.S. News \& World Report, which incorporate students' entrance exam scores - to admit students with a high ACT composite score, even if this score turns out to be unhelpful.

There are many ways to improve the higher education system, but it often seems that complex problems 9such as low college retention rates) require complex solutions. We argue in this case that a better understanding of how the ACT predicts future performance could lead to easily implementable, low-cost solutions that can yield potentially large benefits.

\section{References}

Bettinger, E. and R. Baker. 2011. The Effects of College Coaching on Student Retention: Evidence from a Randomized Experiment in Student Mentoring. NBER Working Paper.

Bowen, W.G. and D. Bok. 1998. The Shape of the River: Long-term Consequences of Considering Race in College and University Admissions. Princeton NJ: Princeton University Press.

Bowen, W.G., Chingos, M.M., and M.S. McPherson. 2009. Crossing the Finish Line: Completing College at America's Public Universities. Princeton, N.J.: Princeton University Press.

Brewer, D.J., Eide, E.R., and R.G. Ehrenberg. 1999. "Does it Pay to Attend and Elite Private College?," Journal of Human Resources, 34(1): 104-123. 
Burton, N.W. and Ramist, L. 2001. "Predeicting Sucess in College: SAT Studies of Classes Graduating Since 1980," College Board Report No. 2001-2. New York: The College Board.

DeBrock, L., Hendricks, W., and R. Koenker. 1996. "The Economics of Persistence: Graduation Rates of Athletes as Labor Market Choice," Journal of Human Resources, 31: 513-539.

DesJardins, S.L., Ahlburg, D.A., and B.P. McCall. 2002. "A Temporal Investigation of Factors Related to Timely Degree Completion," The Journal of Higher Education, 73(5): 555-581.

Dynarski, S.M. 2003. "Does Aid Matter? Measuring the Effect of Student Aid on College Attendance and Completion," American Economic Review, 83(1): 279-288.

Kaplan, D. A. 2009. “The Standardized-test Smackdown.” Fortune 30 November 2009.

Munday, L. 1967. "Predicting College Grades Using ACT Data," Educational and Psychological Measurement 27: 410-406.

Radford, A.W., Berkner, L., Wheeless, S.C., and Shepherd, B. 2010. "Persistence and Attainment of 2003-04 Beginning Postsecondary Students: After 6 Years," NCES 2011-151. U.S. Department of Education, Washington, DC: National Center for Education Statistics.

Rothstein, J.M. 2004. "College Performance Prediction and the SAT," Journal of Econometrics 121: 297317.

Rothstein, J.M. Forthcoming. "SAT Scores, High Schools, and Collegiate Performance Predictions," in Rethinking Admissions for a New Millennium: Moving Past the SAT for Social Diversity and Academic Excellence, J.A. Soares, ed., Teacher's College Press.

Singell, L.D., Jr. 2004. "Come and Stay a While: Does Financial Aid Effect Enrollment and Retention at a Large Public University?," Economics of Education Review, 23: 459-472.

Spady, W. 1970. "Dropouts from Higher Education: An Interdisciplinary Review and Synthesis," Interchange, 1: 64-85.

Tinto, V. 1975. "Dropout from Higher Education: A Theoretical Synthesis of Recent Research," Review of Educational Research, 45, 89-125. 
U.S. News \& World Report. 2011. "National University Rankings."

http:/ / colleges.usnews.rankingsandreviews.com/best-colleges/rankings/nationaluniversities. Accessed on April 21, 2011. 


\section{Appendix 1: Admission Office Interview Protocol}

Institution:

Date:

Interviewee:

Questions:

Why do you use ACT scores in the admission process?

Do you use it because it predicts first year grades, retention, or graduation?

In general, how do you use ACT scores in the admission process?

Does your institution focus on the composite score or the individual subject scores?

When you are evaluating an application, are all of the individual subject scores available for your review?

Can you explain how you might differently evaluate an applicant who intends to enter an engineering or science major?

When considering applicants for engineering or science majors, do you give more weight to the math and science scores on the ACT?

Have you conducted institutional research to examine how well ACT scores predict these outcomes at your campus?

If so, would you be willing to share those results?

Do you adjust admission practices based on academic research?

Would you be willing to do so?

Is there any academic research that could be conducted that could help you to improve the admission process at your institution? 
Figure 1 - College GPA. This figure plots first- and second-year college GPA against how well students did on a math-english composite score relative to their overall composite score. For example, panel A plots the average first-year gpa for students whose math-english composite ((math + english)/2) minus their ACT composite score ranged anywhere from -4 to 4 . A linear trendline is also included.

\section{A. First-Year College GPA}

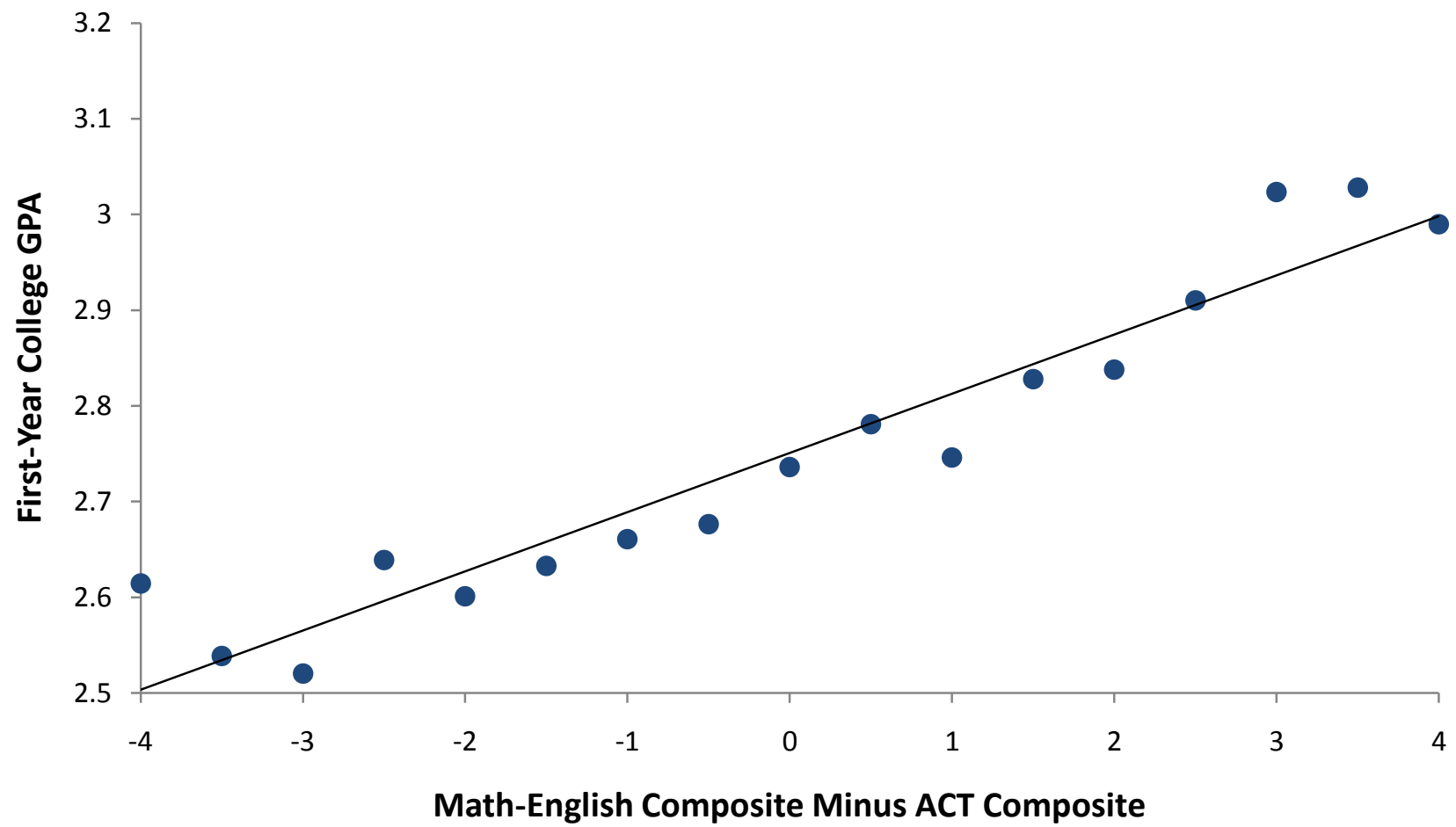

B. Second-Year College GPA

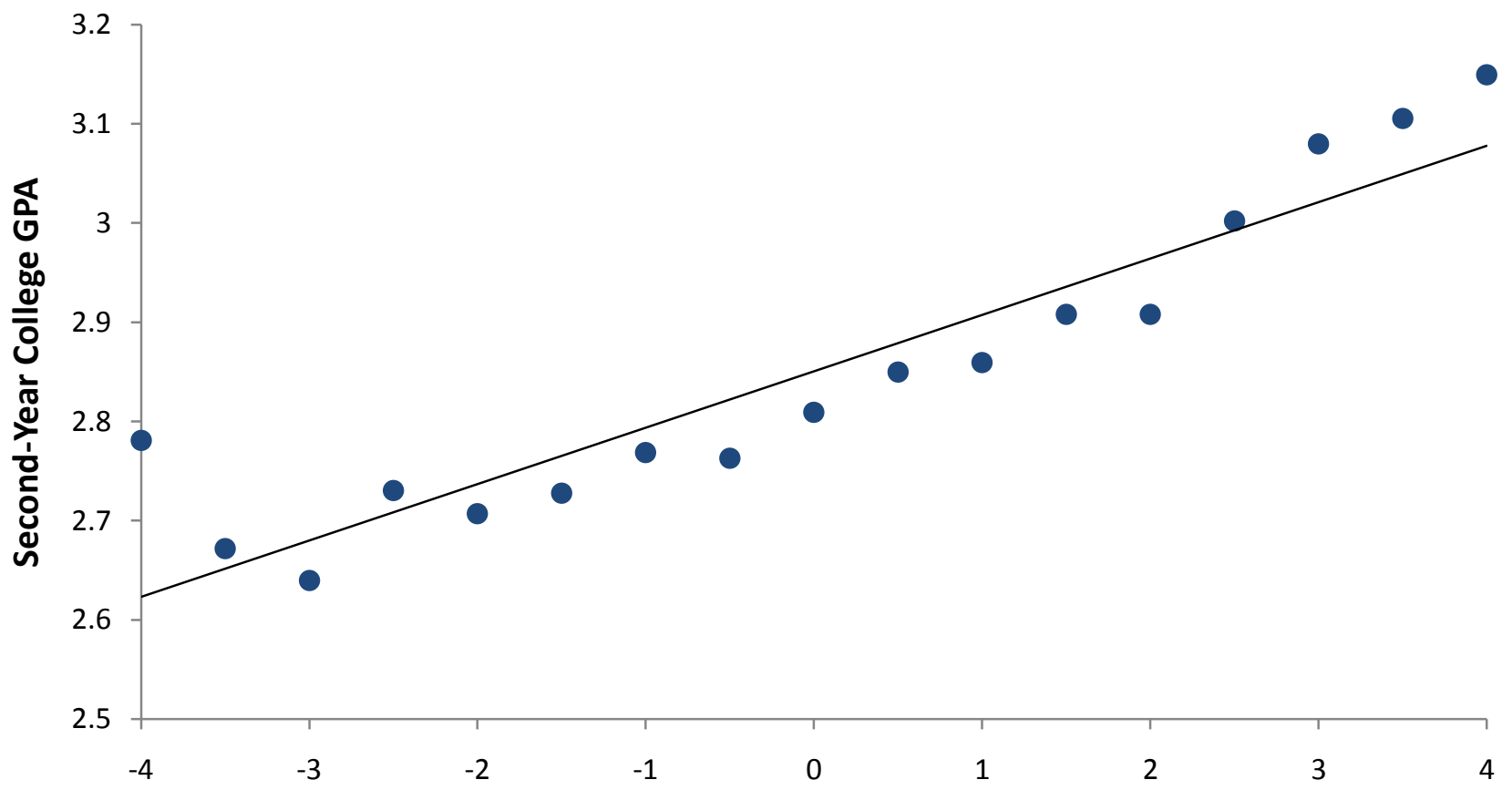

Math-English Composite Minus ACT Composite 
Figure 2 - Dropout Rates. This figure plots first- and third-year college dropout rates against how well students did on a math-english ACT composite score relative to their overall composite score. For example, panel A plots the first-year dropout rate for students whose math-english composite ((math + english)/2) minus their ACT composite score ranged anywhere from -4 to 4 . A linear trendline is also included.

A. First-Year College Dropout Rates

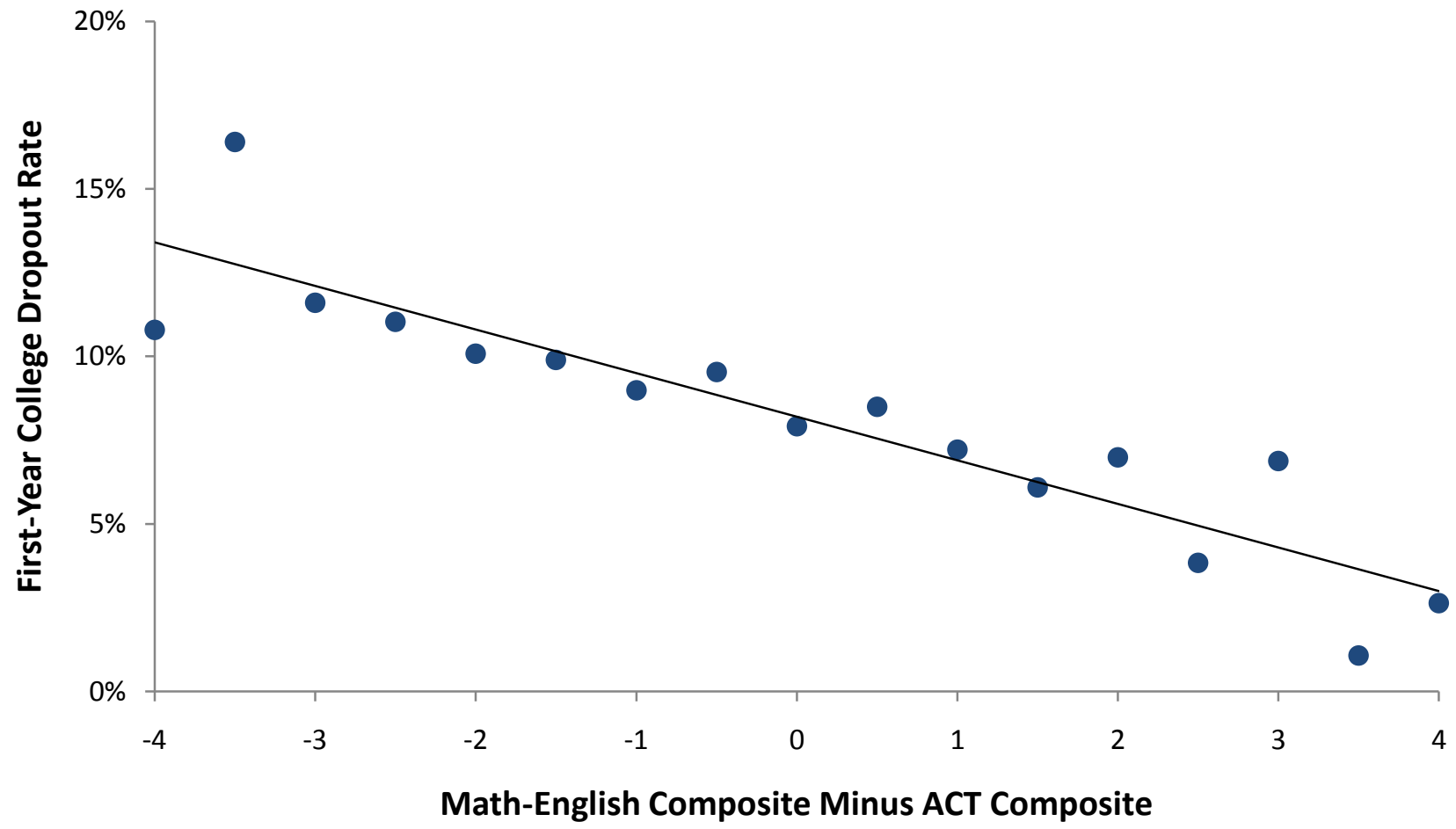

B. Third-Year College Dropout Rates

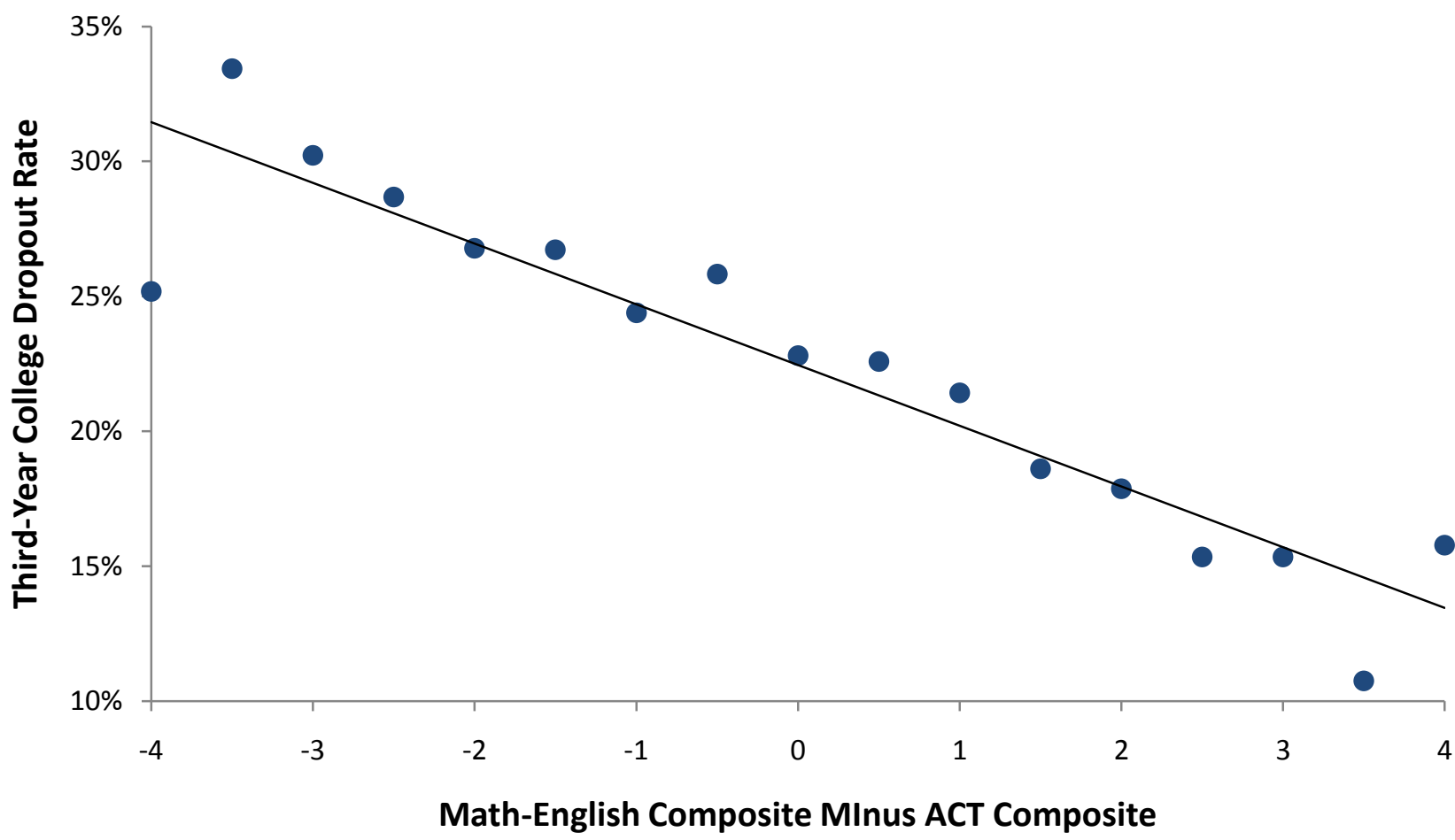




\section{Table 1. Summary Statistics}

\begin{tabular}{|c|c|c|}
\hline & Mean & Standard Deviation \\
\hline First-Year College GPA & 2.71 & 0.85 \\
\hline Second-Year College GPA & 2.80 & 0.68 \\
\hline First-Year Dropout Rate & 0.09 & 0.28 \\
\hline Third-Year Dropout Rate & 0.24 & 0.43 \\
\hline High School GPA (Scale 1-7) & 5.95 & 1.06 \\
\hline ACT Composite Score & 22.27 & 4.25 \\
\hline ACT Math Score & 22.13 & 4.77 \\
\hline ACT English Score & 21.67 & 4.97 \\
\hline ACT Reading Score & 22.66 & 5.56 \\
\hline ACT Science Score & 22.14 & 4.21 \\
\hline Fraction Male & 0.46 & 0.50 \\
\hline Fraction White & 0.85 & 0.36 \\
\hline Fraction Black & 0.08 & 0.28 \\
\hline Fraction Hispanic & 0.02 & 0.12 \\
\hline Fraction Asian & 0.02 & 0.14 \\
\hline Fraction Other/Unknown Race & 0.03 & 0.17 \\
\hline Observations & 25,645 & 25,645 \\
\hline
\end{tabular}

Notes: Data were obtained from the Ohio Board of Regents. Data represent all ACTtaking students who matriculated to a four-year public university in Ohio in 1999. 
Table 2. The Predictive Power of ACT Subscores on First-Year College GPA

\begin{tabular}{|c|c|c|c|c|c|c|}
\hline \multirow[b]{3}{*}{ ACT Composite Score } & \multicolumn{6}{|c|}{ Dependent Variable: First-Year College GPA } \\
\hline & $(1)$ & $(2)$ & (3) & $(4)$ & $(5)$ & (6) \\
\hline & $\begin{array}{l}.072^{* *} \\
(0.001)\end{array}$ & & & & & \\
\hline ACT Math Score & & $\begin{array}{l}0.034^{\star *} \\
(0.002)\end{array}$ & $\begin{array}{l}0.034^{* *} \\
(0.002)\end{array}$ & $\begin{array}{l}0.016^{\star *} \\
(0.002)\end{array}$ & $\begin{array}{l}0.020^{* *} \\
(0.002)\end{array}$ & $\begin{array}{l}0.026 * * \\
(0.002)\end{array}$ \\
\hline ACT English Score & & $\begin{array}{l}0.037^{* *} \\
(0.002)\end{array}$ & $\begin{array}{l}0.036^{* *} \\
(0.002)\end{array}$ & $\begin{array}{l}0.023^{* *} \\
(0.002)\end{array}$ & $\begin{array}{l}0.018^{* *} \\
(0.002)\end{array}$ & $\begin{array}{l}0.016^{* *} \\
(0.002)\end{array}$ \\
\hline ACT Reading Score & & $\begin{array}{l}0.005^{\star *} \\
(0.001)\end{array}$ & $\begin{array}{l}0.005^{\star *} \\
(0.001)\end{array}$ & $\begin{array}{l}0.004^{* *} \\
(0.001)\end{array}$ & $\begin{array}{l}0.003^{*} \\
(0.001)\end{array}$ & $\begin{array}{l}0.003^{*} \\
(0.001)\end{array}$ \\
\hline АCT Science Score & & $\begin{array}{l}-0.004^{*} \\
(0.002)\end{array}$ & $\begin{array}{l}-0.004^{*} \\
(0.002)\end{array}$ & $\begin{array}{l}-0.004^{*} \\
(0.002)\end{array}$ & $\begin{array}{l}-0.002 \\
(0.002)\end{array}$ & $\begin{array}{l}-0.001 \\
(0.002)\end{array}$ \\
\hline Campus Fixed Effects & & & $x$ & $x$ & $x$ & $x$ \\
\hline High School GPA Fixed Effects & & & & $x$ & $\mathrm{x}$ & $x$ \\
\hline Race and Gender Fixed Effects & & & & & $x$ & $x$ \\
\hline College Major Fixed Effects & & & & & & $x$ \\
\hline R-Squared & 0.128 & 0.141 & 0.165 & 0.225 & 0.231 & 0.251 \\
\hline Observations & 25,243 & 25,243 & 25,243 & 24,168 & 24,168 & 21,757 \\
\hline
\end{tabular}


Table 3. The Predictive Power of ACT Subscores on Second-Year College GPA

\begin{tabular}{|c|c|c|c|c|c|c|}
\hline \multirow[b]{3}{*}{ ACT Composite Score } & \multicolumn{6}{|c|}{ Dependent Variable: Second-Year College GPA } \\
\hline & $(1)$ & (2) & $(3)$ & $(4)$ & $(5)$ & $(6)$ \\
\hline & $\begin{array}{l}.072^{* *} \\
(0.001)\end{array}$ & & & & & \\
\hline ACT Math Score & & $\begin{array}{l}0.031^{* *} \\
(0.001)\end{array}$ & $\begin{array}{l}0.033^{\star *} \\
(0.001)\end{array}$ & $\begin{array}{l}0.016^{\star *} \\
(0.001)\end{array}$ & $\begin{array}{l}0.020^{\star *} \\
(0.001)\end{array}$ & $\begin{array}{l}0.026^{\star \star} \\
(0.001)\end{array}$ \\
\hline ACT English Score & & $\begin{array}{l}0.037^{* *} \\
(0.001)\end{array}$ & $\begin{array}{l}0.036^{* *} \\
(0.001)\end{array}$ & $\begin{array}{l}0.023^{\star *} \\
(0.001)\end{array}$ & $\begin{array}{l}0.018^{* *} \\
(0.001)\end{array}$ & $\begin{array}{l}0.016^{* *} \\
(0.001)\end{array}$ \\
\hline ACT Reading Score & & $\begin{array}{l}0.006^{* *} \\
(0.001)\end{array}$ & $\begin{array}{l}0.006^{* *} \\
(0.001)\end{array}$ & $\begin{array}{l}0.005^{\star *} \\
(0.001)\end{array}$ & $\begin{array}{l}0.004^{* *} \\
(0.001)\end{array}$ & $\begin{array}{l}0.004^{* *} \\
(0.001)\end{array}$ \\
\hline ACT Science Score & & $\begin{array}{l}-0.003^{*} \\
(0.002)\end{array}$ & $\begin{array}{l}-0.003^{*} \\
(0.002)\end{array}$ & $\begin{array}{l}-0.004^{*} \\
(0.002)\end{array}$ & $\begin{array}{l}-0.001 \\
(0.002)\end{array}$ & $\begin{array}{c}0.001 \\
(0.002)\end{array}$ \\
\hline Campus Fixed Effects & & & $\mathrm{x}$ & $x$ & $x$ & $\mathrm{x}$ \\
\hline High School GPA Fixed Effects & & & & $x$ & $x$ & $\mathrm{x}$ \\
\hline Race and Gender Fixed Effects & & & & & $x$ & $x$ \\
\hline College Major Fixed Effects & & & & & & $x$ \\
\hline R-Squared & 0.200 & 0.217 & 0.227 & 0.321 & 0.333 & 0.363 \\
\hline Observations & 22,199 & 22,199 & 22,199 & 21,285 & 21,285 & 19,213 \\
\hline
\end{tabular}

Notes: Coefficient values and robust standard errors are presented from OLS regressions of second-year college gpa on the composite act score (Column (1)) and each of the ACT subscores (Columns (2)-(6)). Campus fixed effects are indicators for the campus to which the student matriculated. High school gpa fixed effects are indicators for each of the possible high school gpa levels (scale from 1 to 7 ). Race and gender fixed effects are indicators for gender and each of seven race categories. College major fixed effects are indicators for each of 293 potential college majors chosen by the student.

* significant at $5 \%$; ** significant at $1 \%$ 
Table 4. The Predictive Power of ACT Subscores on First-Year Dropout Indicator

\begin{tabular}{|c|c|c|c|c|c|c|}
\hline \multirow[b]{3}{*}{ ACT Composite Score } & \multicolumn{6}{|c|}{ Dependent Variable: First-Year Dropout Indicator } \\
\hline & (1) & (2) & (3) & (4) & (5) & (6) \\
\hline & $\begin{array}{c}-0.0088^{\star *} \\
(0.0005)\end{array}$ & & & & & \\
\hline ACT Math Score & & $\begin{array}{c}-0.0065^{\star *} \\
(0.0006)\end{array}$ & $\begin{array}{c}-0.0053^{* *} \\
(0.0006)\end{array}$ & $\begin{array}{c}-0.0031^{\star *} \\
(0.0006)\end{array}$ & $\begin{array}{c}-0.0030^{\star *} \\
(0.0007)\end{array}$ & $\begin{array}{c}-0.0025^{\star *} \\
(0.0007)\end{array}$ \\
\hline ACT English Score & & $\begin{array}{c}-0.0046^{* *} \\
(0.0006)\end{array}$ & $\begin{array}{c}-0.0035^{* *} \\
(0.0006)\end{array}$ & $\begin{array}{c}-0.0022^{* *} \\
(0.0006)\end{array}$ & $\begin{array}{l}-0.0021^{* *} \\
(0.0006)\end{array}$ & $\begin{array}{c}-0.0027^{* *} \\
(0.0007)\end{array}$ \\
\hline ACT Reading Score & & $\begin{array}{c}0.0009 \\
(0.0005)\end{array}$ & $\begin{array}{c}0.0011^{*} \\
(0.0005)\end{array}$ & $\begin{array}{l}0.0014^{* *} \\
(0.0005)\end{array}$ & $\begin{array}{l}0.0014^{\star *} \\
(0.0005)\end{array}$ & $\begin{array}{l}0.0014^{* *} \\
(0.0005)\end{array}$ \\
\hline ACT Science Score & & $\begin{array}{c}0.0010 \\
(0.0007)\end{array}$ & $\begin{array}{c}0.0010 \\
(0.0007)\end{array}$ & $\begin{array}{c}0.0013 \\
(0.0007)\end{array}$ & $\begin{array}{c}0.0014 \\
(0.0007)\end{array}$ & $\begin{array}{c}0.0012 \\
(0.0007)\end{array}$ \\
\hline Campus Fixed Effects & & & $x$ & $\mathrm{x}$ & $x$ & $\mathrm{x}$ \\
\hline High School GPA Fixed Effects & & & & $x$ & $x$ & $\mathrm{x}$ \\
\hline Race and Gender Fixed Effects & & & & & $x$ & $x$ \\
\hline College Major Fixed Effects & & & & & & $x$ \\
\hline Pseudo R-Squared & 0.029 & 0.036 & 0.054 & 0.063 & 0.064 & 0.083 \\
\hline Observations & 25,645 & 25,645 & 25,645 & 24,551 & 24,551 & 22,111 \\
\hline
\end{tabular}

Notes: Marginal effects and robust standard errors are presented from Logit regressions of a first-year dropout indicator on the composite act score (Column (1)) and each of the ACT subscores (Columns (2)-(6)). Campus fixed effects are indicators for the campus to which the student matriculated. High school gpa fixed effects are indicators for each of the possible high school gpa levels (scale from 1 to 7 ). Race and gender fixed effects are indicators for gender and each of seven race categories. College major fixed effects are indicators for each of 293 potential college majors chosen by the student.

${ }^{*}$ significant at $5 \%$; ${ }^{* *}$ significant at $1 \%$ 
Table 5. The Predictive Power of ACT Subscores on Third-Year Dropout Indicator

\begin{tabular}{|c|c|c|c|c|c|c|}
\hline \multirow[b]{3}{*}{ ACT Composite Score } & \multicolumn{6}{|c|}{ Dependent Variable: Third-Year Dropout Indicator } \\
\hline & $(1)$ & (2) & (3) & $(4)$ & $(5)$ & (6) \\
\hline & $\begin{array}{l}-0.098^{* \star} \\
(0.004)\end{array}$ & & & & & \\
\hline ACT Math Score & & $\begin{array}{c}-0.013^{\star *} \\
(0.001)\end{array}$ & $\begin{array}{l}-0.011^{* *} \\
(0.001)\end{array}$ & $\begin{array}{c}-0.006^{\star *} \\
(0.001)\end{array}$ & $\begin{array}{c}-0.007^{\star *} \\
(0.001)\end{array}$ & $\begin{array}{c}-0.006^{\star *} \\
(0.001)\end{array}$ \\
\hline ACT English Score & & $\begin{array}{l}-0.008^{\star *} \\
(0.001)\end{array}$ & $\begin{array}{l}-0.005^{* *} \\
(0.001)\end{array}$ & $\begin{array}{c}-0.003^{* *} \\
(0.001)\end{array}$ & $\begin{array}{c}-0.002^{\star *} \\
(0.001)\end{array}$ & $\begin{array}{l}-0.002^{*} \\
(0.001)\end{array}$ \\
\hline ACT Reading Score & & $\begin{array}{l}0.002^{*} \\
(0.001)\end{array}$ & $\begin{array}{l}0.002^{* *} \\
(0.001)\end{array}$ & $\begin{array}{l}0.002^{\star *} \\
(0.001)\end{array}$ & $\begin{array}{l}0.002^{* *} \\
(0.001)\end{array}$ & $\begin{array}{l}0.003^{* *} \\
(0.001)\end{array}$ \\
\hline ACT Science Score & & $\begin{array}{c}0.002 \\
(0.001)\end{array}$ & $\begin{array}{c}0.002 \\
(0.001)\end{array}$ & $\begin{array}{l}0.002^{*} \\
(0.001)\end{array}$ & $\begin{array}{l}0.002^{*} \\
(0.001)\end{array}$ & $\begin{array}{l}0.002^{*} \\
(0.001)\end{array}$ \\
\hline Campus Fixed Effects & & & $x$ & $x$ & $x$ & $x$ \\
\hline High School GPA Fixed Effects & & & & $x$ & $x$ & $x$ \\
\hline Race and Gender Fixed Effects & & & & & $\mathrm{x}$ & $x$ \\
\hline College Major Fixed Effects & & & & & & $x$ \\
\hline Pseudo R-Squared & 0.028 & 0.035 & 0.063 & 0.077 & 0.0775 & 0.098 \\
\hline Observations & 25,645 & 25,645 & 25,645 & 24,551 & 24,551 & 22,111 \\
\hline
\end{tabular}

Notes: Marginal effects and robust standard errors are presented from Logit regressions of a third-year dropout indicator on the composite act score (Column (1)) and each of the ACT subscores (Columns (2)-(6)). Campus fixed effects are indicators for the campus to which the student matriculated. High school gpa fixed effects are indicators for each of the possible high school gpa levels (scale from 1 to 7 ). Race and gender fixed effects are indicators for gender and each of seven race categories. College major fixed effects are indicators for each of 293 potential college majors chosen by the student.

${ }^{*}$ significant at $5 \%$; ${ }^{* *}$ significant at $1 \%$ 
Table 6. The Predictive Power of ACT Subscores on First-Year College GPA - By University

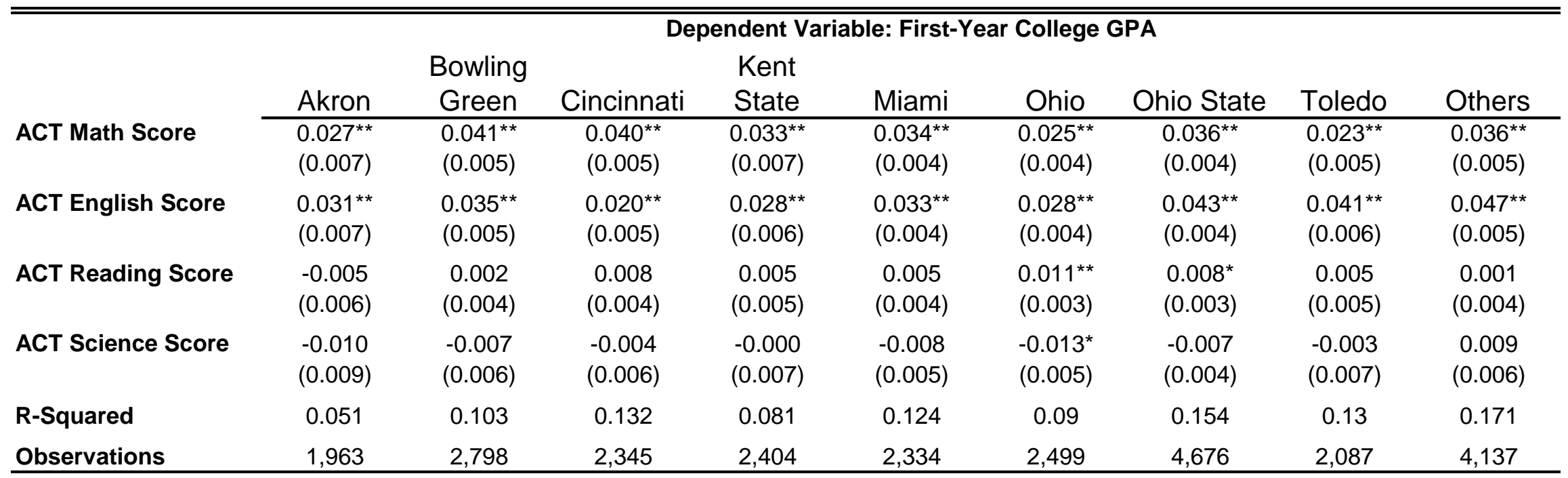

Notes: Coefficient values and robust standard errors are presented from OLS regressions of first-year college gpa on each of the ACT subscores.

Each column is restricted to data from the university indicated. The last column includes data from 5 schools (Youngstown State, Wright State,

Shawnee State, Cleveland State, and Central State) due to small samples from each of these 5 schools.

* significant at $5 \%$; ** significant at $1 \%$ 
Table 7. The Predictive Power of ACT Subscores on Third-Year Dropout Indicator - By University

\begin{tabular}{|c|c|c|c|c|c|c|c|c|c|}
\hline & & & Depe & ent Vari & $\overline{\text { Thrid-Ye }}$ & ropout Ir & icator & & \\
\hline & Akron & $\begin{array}{c}\text { Bowling } \\
\text { Green }\end{array}$ & Cincinnati & $\begin{array}{l}\text { Kent } \\
\text { State }\end{array}$ & Miami & Ohio & Ohio State & Toledo & Others \\
\hline ACT Math Score & $\begin{array}{c}-0.009^{* *} \\
(0.003)\end{array}$ & $\begin{array}{l}-0.004 \\
(0.003)\end{array}$ & $\begin{array}{c}-0.022^{* *} \\
(0.003)\end{array}$ & $\begin{array}{l}-0.007^{*} \\
(0.003)\end{array}$ & $\begin{array}{c}-0.006^{* \star} \\
(0.002)\end{array}$ & $\begin{array}{c}-0.007^{* *} \\
(0.002)\end{array}$ & $\begin{array}{c}-0.010^{* *} \\
(0.002)\end{array}$ & $\begin{array}{c}-0.014^{* *} \\
(0.003)\end{array}$ & $\begin{array}{r}-0.016^{*} \\
(0.003)\end{array}$ \\
\hline ACT English Score & $\begin{array}{c}-0.012^{* *} \\
(0.003)\end{array}$ & $\begin{array}{l}-0.004 \\
(0.002)\end{array}$ & $\begin{array}{l}-0.007^{*} \\
(0.003)\end{array}$ & $\begin{array}{l}-0.007^{*} \\
(0.003)\end{array}$ & $\begin{array}{l}-0.004 \\
(0.002)\end{array}$ & $\begin{array}{l}-0.002 \\
(0.002)\end{array}$ & $\begin{array}{l}-0.005^{*} \\
(0.002)\end{array}$ & $\begin{array}{l}-0.008^{*} \\
(0.003)\end{array}$ & $\begin{array}{c}-0.004^{*} \\
(0.002)\end{array}$ \\
\hline ACT Reading Score & $\begin{array}{c}0.004 \\
(0.003)\end{array}$ & $\begin{array}{c}0.003 \\
(0.002)\end{array}$ & $\begin{array}{c}0.002 \\
(0.003)\end{array}$ & $\begin{array}{l}-0.002 \\
(0.003)\end{array}$ & $\begin{array}{c}0.002 \\
(0.002)\end{array}$ & $\begin{array}{c}0.001 \\
(0.002)\end{array}$ & $\begin{array}{c}0.001 \\
(0.001)\end{array}$ & $\begin{array}{c}0.005 \\
(0.003)\end{array}$ & $\begin{array}{c}0.003 \\
(0.002)\end{array}$ \\
\hline ACT Science Score & $\begin{array}{l}-0.001 \\
(0.004)\end{array}$ & $\begin{array}{c}0.003 \\
(0.003)\end{array}$ & $\begin{array}{c}0.08^{*} \\
(0.004)\end{array}$ & $\begin{array}{l}-0.001 \\
(0.004)\end{array}$ & $\begin{array}{c}0.002 \\
(0.002)\end{array}$ & $\begin{array}{c}0.000 \\
(0.003)\end{array}$ & $\begin{array}{c}0.003 \\
(0.002)\end{array}$ & $\begin{array}{c}0.002 \\
(0.004)\end{array}$ & $\begin{array}{l}-0.000 \\
(0.003)\end{array}$ \\
\hline Pseudo R-Squared & 0.022 & 0.002 & 0.041 & 0.017 & 0.015 & 0.008 & 0.018 & 0.023 & 0.018 \\
\hline Observations & 2.051 & 2.836 & 2.369 & 2.456 & 2.340 & 2.538 & 4.696 & 2.142 & 4.217 \\
\hline
\end{tabular}

Notes: Marginal effects and robust standard errors are presented from Logit regressions of a third-year dropout indicator on each of the ACT

subscores. Each column is restricted to data from the university indicated. The last column includes data from 5 schools (Youngstown State, Wright State, Shawnee State, Cleveland State, and Central State) due to small samples from each of these 5 schools.

${ }^{*}$ significant at $5 \%$; ** significant at $1 \%$ 
Table 8. The Predictive Power of ACT Subscores on High School GPA

\begin{tabular}{lccc}
\hline \hline & \multicolumn{3}{c}{ Dependent Variable: High School GPA (Scale 1-7) } \\
ACT Composite Score & $(1)$ & $(2)$ & $(3)$ \\
\cline { 2 - 4 } & $0.136^{* *}$ & & \\
ACT Math Score & $(0.001)$ & $0.073^{\star *}$ & $0.084^{\star *}$ \\
& & $(0.002)$ & $(0.002)$ \\
ACT English Score & $0.055^{\star *}$ & $0.039^{\star *}$ \\
ACT Reading Score & $(0.002)$ & $(0.002)$ \\
& & $0.004^{\star *}$ & 0.002 \\
ACT Science Score & & $(0.002)$ & $(0.002)$ \\
& & $0.007^{\star *}$ & $0.018^{\star *}$ \\
Race and Gender Fixed Effects & & $(0.002)$ & $(0.002)$ \\
R-Squared & & & $X$ \\
Observations & 0.295 & 0.323 & 0.353 \\
\hline
\end{tabular}

Notes: Coefficient values and robust standard errors are presented from OLS regressions of high school gpa (scale 1-7) on the composite act score (Column (1)) and each of the ACT subscores (Columns (2) and(3)). Race and gender fixed effects are indicators for gender and each of seven race categories.

${ }^{*}$ significant at $5 \%$; ** significant at $1 \%$ 
Table 9. The Predictive Power of ACT Subscores on College and High School GPA - BYU Sample

\begin{tabular}{|c|c|c|c|}
\hline & \multicolumn{2}{|c|}{ College GPA } & \multirow{2}{*}{$\begin{array}{c}\text { High School GPA } \\
\text { (3) }\end{array}$} \\
\hline & (1) & (2) & \\
\hline ACT Math Score & $\begin{array}{l}0.015^{\star *} \\
(0.002)\end{array}$ & $\begin{array}{l}0.015^{\star *} \\
(0.002)\end{array}$ & $\begin{array}{l}0.016^{* *} \\
(0.002)\end{array}$ \\
\hline ACT English Score & $\begin{array}{l}0.019^{* *} \\
(0.003)\end{array}$ & $\begin{array}{l}0.019^{\star *} \\
(0.003)\end{array}$ & $\begin{array}{l}0.010^{* *} \\
(0.002)\end{array}$ \\
\hline ACT Reading Score & $\begin{array}{l}0.006^{\star *} \\
(0.002)\end{array}$ & $\begin{array}{l}0.007^{\star \star} \\
(0.002)\end{array}$ & $\begin{array}{c}0.002 \\
(0.002)\end{array}$ \\
\hline ACT Science Score & $\begin{array}{c}0.003 \\
(0.002)\end{array}$ & $\begin{array}{c}0.001 \\
(0.002)\end{array}$ & $\begin{array}{c}0.002 \\
(0.002)\end{array}$ \\
\hline Gender Fixed Effect & $x$ & $x$ & $x$ \\
\hline Major Fixed Effects & & $x$ & \\
\hline R-Squared & 0.192 & 0.443 & 0.132 \\
\hline Observations & 1,712 & 1,712 & 1,706 \\
\hline
\end{tabular}

Notes: Coefficient values and robust standard errors are presented from OLS regressions of graduating college gpa (Columns (1) and (2)) and high school gpa (Column (3)) on each of the ACT subscores. An indicator for gender is included and also indicators for each of 358 potential college majors (Column (2)).

${ }^{*}$ significant at $5 \% ;{ }^{* *}$ significant at $1 \%$ 
Table 10. The Predictive Power of a Math-English Composite Score on Academic Success

\begin{tabular}{|c|c|c|c|c|c|c|c|c|}
\hline & \multicolumn{8}{|c|}{ Dependent Variable } \\
\hline & \multicolumn{2}{|c|}{ First-Year GPA } & \multicolumn{2}{|c|}{ Second-Year GPA } & \multicolumn{2}{|c|}{$\begin{array}{l}\text { First-Year Dropout } \\
\text { Indicator }\end{array}$} & \multicolumn{2}{|c|}{$\begin{array}{l}\text { Third-Year Dropout } \\
\text { Indicator }\end{array}$} \\
\hline & $(1)$ & $(2)$ & (3) & $(4)$ & (5) & (6) & $(7)$ & $(8)$ \\
\hline Math-English Composite Score & $\begin{array}{l}0.066^{\star \star} \\
(0.004)\end{array}$ & $\begin{array}{l}0.040^{\star \star} \\
(0.004)\end{array}$ & $\begin{array}{l}0.060^{* *} \\
(0.003)\end{array}$ & $\begin{array}{l}0.036^{* *} \\
(0.003)\end{array}$ & $\begin{array}{l}-0.013^{\star *} \\
(0.001)\end{array}$ & $\begin{array}{l}-0.008^{* *} \\
(0.001)\end{array}$ & $\begin{array}{l}-0.026^{* *} \\
(0.002)\end{array}$ & $\begin{array}{l}-0.013^{* *} \\
(0.002)\end{array}$ \\
\hline ACT Composite Score & $\mathrm{X}$ & $\mathrm{x}$ & $\mathrm{X}$ & $\mathrm{X}$ & $\mathrm{X}$ & $\mathrm{X}$ & $\mathrm{X}$ & $\mathrm{X}$ \\
\hline Campus Fixed Effects & & $\mathrm{x}$ & & $\mathrm{x}$ & & $\mathrm{x}$ & & $\mathrm{x}$ \\
\hline High School GPA Fixed Effects & & $x$ & & $x$ & & $x$ & & $x$ \\
\hline Race and Gender Fixed Effects & & $x$ & & $x$ & & $x$ & & $x$ \\
\hline College Major Fixed Effects & & $\mathrm{x}$ & & $\mathrm{x}$ & & $x$ & & $\mathrm{x}$ \\
\hline R-Squared/Pseudo R-Squared & 0.140 & 0.251 & 0.216 & 0.362 & 0.036 & 0.083 & 0.034 & 0.097 \\
\hline Observations & 25,243 & 21,757 & 22,199 & 19,213 & 25,645 & 21,410 & 25,645 & 21,967 \\
\hline
\end{tabular}

Notes: Coefficients (Columns (1)-(4)) and marginal effects (Columns (5)-(8)) and robust standard errors are presented from OLS/Logit regressions where the dependent variable is first-year GPA (Columns (1) and (2)), second-year GPA (Columns (3) and (4)), first-year dropout indicator (Columns (5) and (6)), and second-year dropout indicator (Columns (7) and (8)). The key independent variable is the math-english composite score which we generate by taking the average of the math and english test scores. In Columns (1), (3), (5), and (7) we control for the actual ACT composite score (unrounded) and in Columns (2), (4), (6), and (8) we also control for our full set of control variables.

${ }^{*}$ significant at $5 \%$; ${ }^{* *}$ significant at $1 \%$ 
Table 11. Calibration Results

\begin{tabular}{|c|c|c|c|}
\hline & \multicolumn{3}{|c|}{$\begin{array}{c}\text { Callibration Results of 3rd-Year Dropout Rates by School Using } \\
\text { Different Hypothetical Admission Rules }\end{array}$} \\
\hline & $\begin{array}{c}\text { Using ACT } \\
\text { Composite Score } \\
\text { Rank }\end{array}$ & $\begin{array}{l}\text { Using Math-English } \\
\text { Score Rank }\end{array}$ & $\begin{array}{c}\text { Percent } \\
\text { Difference in Dropou } \\
\text { Rates }\end{array}$ \\
\hline Miami University & 0.156 & 0.144 & $-7.7 \%$ \\
\hline Ohio University & 0.147 & 0.140 & $-4.8 \%$ \\
\hline Ohio State University & 0.188 & 0.182 & $-3.2 \%$ \\
\hline Bowling Green State University & 0.209 & 0.205 & $-1.9 \%$ \\
\hline University of Cincinnati & 0.220 & 0.222 & $0.9 \%$ \\
\hline Univrsity of Akron & 0.239 & 0.247 & $3.3 \%$ \\
\hline Kent State University & 0.261 & 0.278 & $6.5 \%$ \\
\hline University of Toledo & 0.315 & 0.304 & $-3.5 \%$ \\
\hline Cleveland State University & 0.311 & 0.319 & $2.6 \%$ \\
\hline Youngstown State University & 0.345 & 0.363 & $5.2 \%$ \\
\hline Wright State University & 0.411 & 0.415 & $1.0 \%$ \\
\hline Shawnee State University & 0.458 & 0.486 & $6.1 \%$ \\
\hline Central State University & 0.528 & 0.560 & $6.1 \%$ \\
\hline
\end{tabular}

Notes: This table provides the 3rd-year dropout rates for the students admitted to each college under two hypothetical admission plans. The first plan assigns the best students (as measured by their ACT composite scores) to the highest-rated Universities. The second plan assigns the best students (as measured by their Mathematics-English composite score) to the highest-rated Universities. The first two columns in the table indicate the 3rd-year dropout rates for the students assigned to each university based on the two different assignment plans. The 3rd column provides the percent difference in dropout rates between the two plans. 